\title{
成長ホルモン産生下垂体腺腫に合併する高プロラクチン血症 発症の病態に関する内分泌学的ならびに組織学的研究
}

\author{
河島 研吾·魚住 徹·迫田 勝明 - 向田 一敏 ·大田 正博* \\ Hyperprolactinemia associated with Growth Hormone-secreting Pituitary \\ Adenoma
}

Endocrinological and Histological Evaluation

\author{
Kengo Kawashima, Tohru Uozumi, Katsuaki Sakoda, Kazutoshi MuKada \\ and Masahiro OHTA*
}

Department of Neurosurgery, Hiroshima University, Hiroshima; ${ }^{*}$ Department of Neurosurgery, Ehime Prefectural Central Hospital, Matsuyama

\begin{abstract}
Forty patients with growth hormone $(\mathrm{GH})$-secreting pituitary adenomas were included in a histological and endocrinological investigation. Thirteen were found to have hyperprolactinemia. Light and electron microscopic studies showed no morphological differences between the adenomas of patients with and without hyperprolactinemia. Neither mammosomatotroph cell adenoma nor acidophil stem cell adenoma was detected in GH-secreting pituitary adenomas associated with hyperprolactinemia. Immunohistochemical study revealed $90 \%$ of the tumors to contain prolactin (PRL) -positive cells, in both patients with hyperprolactinemia and those with normal PRL values. These findings suggest that GH-secreting pituitary adenoma might more accurately be termed "mixed GH cell-PRL cell adenoma." In addition, there was a statistically significant correlation between the preoperative serum PRL values and the proportion of immunoreactive PRL-secreting in the tumor cells $(\mathrm{p}<0.05)$. Among the 13 hyperprolactinemic patients, three whose tumors contained few or no immunoreactive PRL-secreting cells were nonresponders to thyrotropin releasing hormone (TRH). In one of these patients the tumor protruded into the suprasellar region and the suspected cause of the hyperprolactinemia was interference with the release of prolactin inhibitory factor. In the other two patients the hyperprolactinemia could not be explained. The remaining 10 hyperprolactinemic patients responded to TRH and their tumors contained many immunoreactive PRL-secreting cells. Thus, it appears that in TRH responders the hyperprolactinemia was attributable to PRL secretion within the tumor.
\end{abstract}

Key words: pituitary adenoma, growth hormone, prolactin, acromegaly

\section{I はじめに}

成長ホルモン $(\mathrm{GH})$ 産生下垂体腺腫症例に高プロラクチ

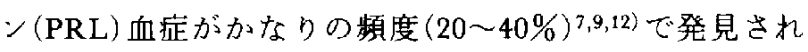

ることは周知の事実であるが，その発症機序は明らかにさ れていない，近年，免疫組穖化学的検査法の進歩により， 組織学的に下垂体腺腫内の各種ホルモンの存在を認識でき るよらになった。そこで我々は，GH 産生下垂体腺腫を組

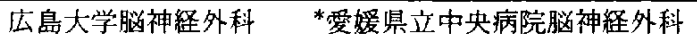

Address reprint requests to: K. Kawashima, M.D., Department of Neurosurgery, Hiroshima University, 1-2-3 Kasumi, Minami-ku, Hiroshima 734.

受稿 1987 年 5 月28日 受理 1988年 3 月28日
} 
織学的に検索 $L$, 内分泌学的検查所見と比較 $L$, 高 PRL 血症発症の病態について検討したので報告する。

\section{II 対象および方法}

\section{1. 対象}

1979年 3 月より1984年 9 月まで経験した GH 産生下 垂体腺腫で，手術時に採取された腫瘍が組織学的に十分検 索可能であった40症例について検討を行った．年夦は10〜 60 才，平均37.9才であり，男性22例，女性18例であった，

\section{2. 方法}

内分泌学的検討：血中 GH おょび PRL 值は radioimmunoassay法により測定し, thyroid releasing hormone (TRH) $500 \mu \mathrm{g}$, luteinizing hormone releasing hormone （LHRH） $100 \mu \mathrm{g}$ のそれぞれの負荷試験による血中 GH 值 の反庍性から，血中 $\mathrm{GH}$ 基礎值上り100\%以上の増加をき たすものをそれぞれの反应型とした。

組織学的模討：経蝶形骨洞法により手術時採取した腫瘍 組織を Bouin 固定 し， hematoxylin-eosine（HE）染色およ び免疫組織化学的検索 (peroxidase-antiperoxidase 法)によ り，GH おょび PRL（GH および PRL 抗体は NIAMDD, Dr. Salvatore Raitiより提供)の免疫反応を検討した．免疫 反応は，吸収試験( GH 掞よび PRL 抗原は Dr. Salvatore Raiti 上り提(共)，交攴試験，positive control, negative control を行い，明らかに濃染する細胞を免疫反応陽性細胞と して判定し，全腫癔細胞に対寸る兔疫反応陽性細胞の割合 （混在率）について検索した。混在率は，明らかに腫瘍性の 増殖を示与部位について randomに 5 力所検索し, その单 位面積当りの全腫瑝細胞中の免疫反応陽性細胞の比率を計 算して平均化し算出した。また，腫瘍組織の一部は採取時

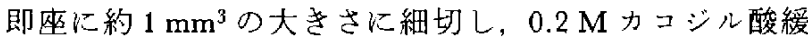
衝 $2 \%$ グルタールアルデヒド，1\%パラホルムアルデヒド 混合液にて 2 時間固定したのち，リン酸緩衝 $1 \%$ オスウ ム酸で1.5時間の後固定を行い, アルコール系列脱水，エ ポン包埋後 Portor-Blum ultramicrotome で超薄切片を作製 し，ウラニウム招よび鉛の二重染色後に日本電子 JBM $100 \mathrm{~B}$ 型電子顕微鏡で観察した。

\section{III 結 果}

\section{1. 内分泌学的検討}

対象とした GH 産生下垂体腺腫40例の術前血中 GH 基 礎值は7.8 385.0 ng/ml, 平均 $65.6 \mathrm{ng} / \mathrm{m} l$ であった。高 PRL 血症（血中 PRL 基䃈値 $25.0 \mathrm{ng} / \mathrm{ml}$ 以上）を示したのは 13例（32.5\%)で，その血中 PRL 基礎值は25.0 1,000 ng/ $\mathrm{m} l$, 平均 $116.0 \mathrm{ng} / \mathrm{m} l$ であった。 また, 各種反応型に劣い て, TRH 反応型が 25 例, LHRH 反応型 4 例, 無反応型
11例であった，高PRL 血症合併例に扎いては，TRH 反 応型10例，無反応型 3 例で，LHRH 反応型の症例はなか った，正常 PRL 値症例，寸なわち高 PRL 血症非合併例 27 例では，TRH 反応型15例， LHRH 反応型 4 例，無反 庆型 8 例であった。

\section{2. 組織学的検討}

\section{1) HE 染色の結果}

従来の腫瘍構築像に上る分類5,10)では，いわゆる diffuse type のもの22例(55\%), sinusoidal type 16例(40\%), papillary type 2 例 (5\%) であった. 正常 PRL 值症例27例では diffuse type 15例 (55.6\%), sinusoidal type 11例 $(40.7 \%)$, papillary type 1 例 (3.7\%) で, 高 PRL 血症合併例13例では diffuse type 8 例 (61.5\%), sinusoidal type 4 例 (30.8\%), papillary type 1 例 $(7.7 \%)$ であり, 高 PRL 血症合併例に特徵は 認められなかった。

次に紐胞質内の染色性汇上る分類では， acidophilic type 19例 (47.5\%), chromophobic type 3 例 (7.5\%), mixed type 18 例 (45\%)であった。正常 PRL 值应例27例では acidophilic type 12例 (44.4\%), chromophobic type 2 例 (7.4\%), mixed type 13例(48.1\%)であるのに対し，高 PRL 血症合 併例13例では acidophilic type 7 例 (53.8\%), chromophobic type 1 例 (7.7\%), mixed type 5 例(38.5\%)であり, 高 PRL 血症合併例は非合併例に比してやや acidophilic type が多 く mixed typeが少ない傾向を認めるものの，有意差はな かった。

\section{2）免疫染色の結果}

ホルモン陽性細胞の陽性率について：ホルモン陽性細胞 はGH 括よび PRLのいずれも散在性に存在し, clusterの よらな集簇状態で存在することはきわめて委れであった （Fig. 1)，多数の組織切片を丹念に検索した上で，明らか に腫場性の增殖を示す組織像の中にホルモン陽性細胞を認 める場合には，たとえその割合がそしくてもホルモン陽性 練胞“存在”之した(Fig. 2)。

明らかな GH 陽性細胞が37例 (92.5\%)に認めら九， PRL 陽性細胞は36例 (90.0\%)に認められた，正常 PRL 值 症例27例では，GH 陽性細胞あるいはPRL 陽性細胞がそ れぞれ24例(各88.9\%)に認められた。一方高 PRL 血埗合 併例13例飞拈いては，GH陽性細胞が全例 $(100 \%)$ K， PRL 陽性紐胞が12例(92.3\%)に認められた。このように， 高PRL 血症例と血中 PRL 值正常例との間で, 腫瘍内に みられるPRL 細胞の存在する率，寸なわち陽性率に有意 差はまったく認められなかった(Table 1).

ホルモン陽性細胞の混在率について：腫瘍内に混在寸る ホルモン陽性紏胞は，観察部位によってその割合がかなり 異なる症例もあることが判明したため, 力法の項で述べた 


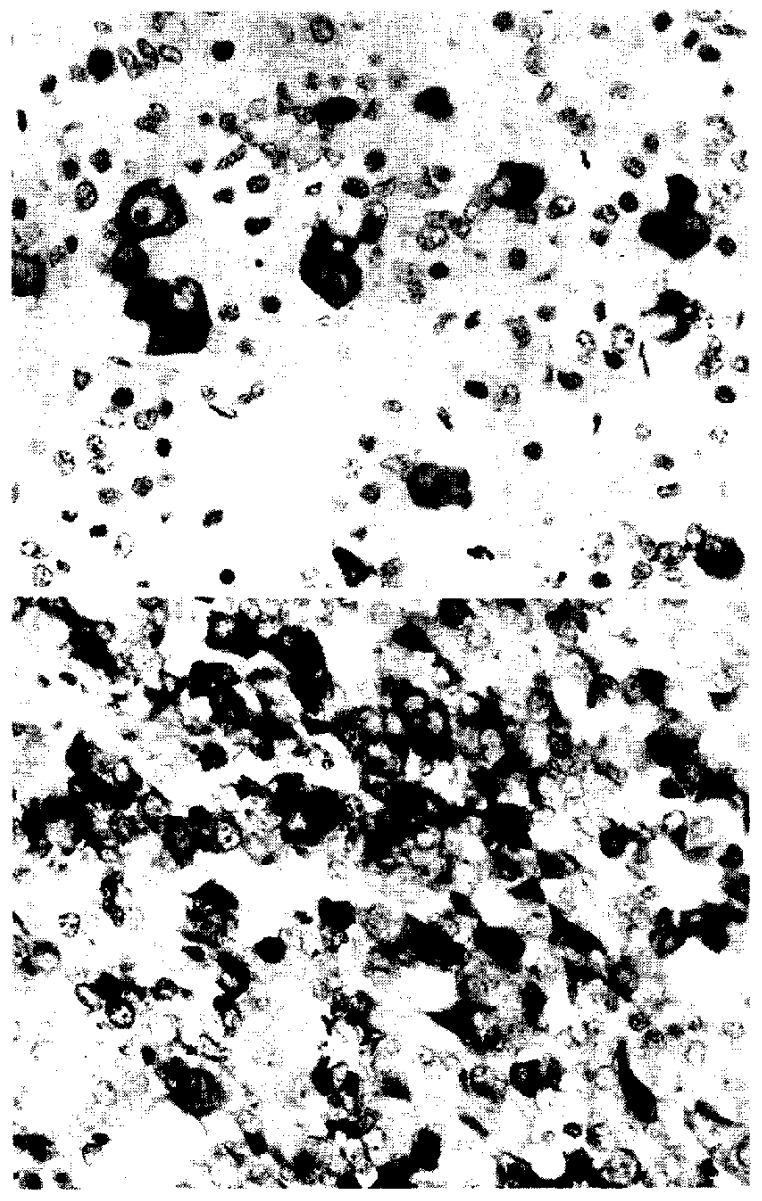

Fig. 1 Immunoreactivities of growth hormone (GH) (upper) and prolactin (PRL) (lower) in $\mathrm{GH}$-secreting pituitary adenoma. Many immunoreactive cells are scattered throughout the tumor. Peroxidase-antiperoxidase (PAP) method, $\times 200$.

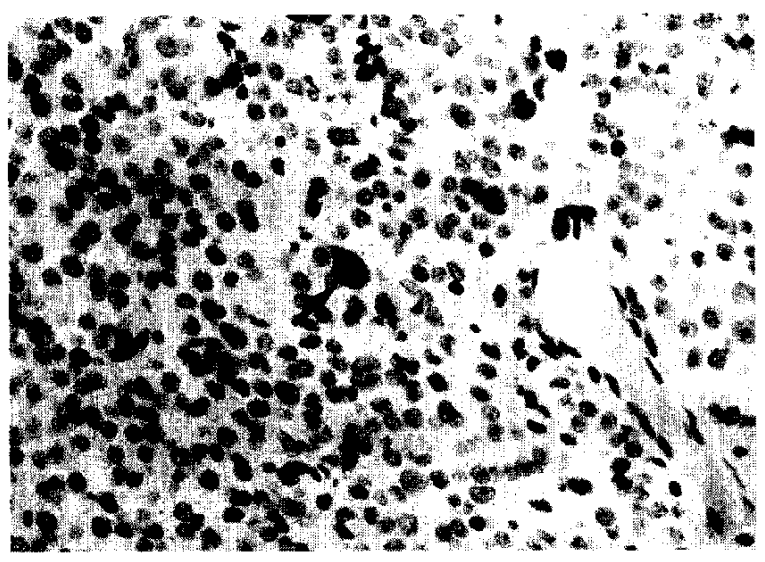

Fig. 2 Immunoreactive PRL-secreting cells are scant within the tumor (arrow). PAP method, $\times 200$.
Table 1 Immunoreactive cells in GH-secreting pituitary adenomas

\begin{tabular}{ccccc}
\hline & \multirow{2}{*}{$\begin{array}{c}\text { No. of } \\
\text { cases }\end{array}$} & \multicolumn{2}{c}{ Immunoreactive cells } \\
\cline { 3 - 5 } & & GH & PRL \\
\hline Normal serum PRL & 27 & 24 & $(88.9 \%)$ & $24(88.9 \%)$ \\
Hyperprolactinemia & 13 & 13 & $(100 \%)$ & $12(92.3 \%)$ \\
\hline Total & 40 & 37 & $(92.5 \%)$ & $36(90.0 \%)$ \\
\hline
\end{tabular}

GH indicates growth hormone; PRL, prolactin.

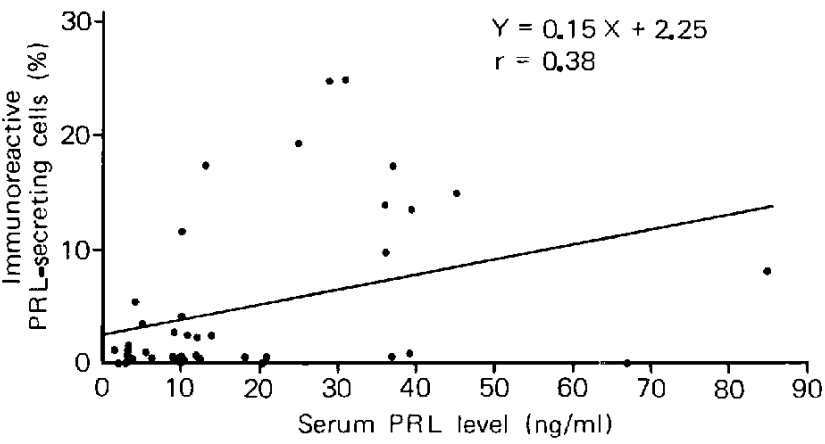

Fig. 3 Correlation between preoperative serum PRL level and the proportion of immunoreactive PRL-secreting cells within the tumor in 40 patients with GH-secreting pituitary adenoma. The regression line is significant $(\mathrm{p}<0.05)$.

ごとくホルモン陽性細胞の占める比率(混在率)を算出し, 血中ホルモン濃度との関係を検討した，腫瘍内に混在する $\mathrm{GH}$ 陽性細胞の混在率と術前血中 $\mathrm{GH}$ 基礎值々の開には 明らかな相関関係汢認められなかったが，高 PRL 血症合 併例 13例の尰瘍内の PRL 陽性細胞の平均混在率は $13.7 \%$ であるのに対し，正常血中 PRL 值症例27例の平均泥在率 は2.4\%と低值であり，PRL陽性細胞の混在率と術前血中 PRL 基礎値との間に正の相関を認めた（p<0.05，Fig. 3).

prolactin inhibitory factor (PIF) 障害に起因すると思わ れる高 PRL 血症について：高 PRL 血症を合併した13例 のら台鞍上部進展を示したのは2例であり，1例では腺腫 内に PRL 陽性細胞が高率に存在したが，他の1例には明 らかな PRL 陽性勫胞は存在せず，この症例では高 PRL 血症の原因として PIF 障害が示唆された。

血中 GH 値の異常反応と高 PRL 血症および PRL 陽性 細胞混在率の関係について (Table 2 4) : 血中 $\mathrm{GH}$ 值の反 応が TRH 反応型であった25例では，腫瘍中の PRL 陽性 細胞が全例 $(100 \%)$ に存在し，ま大その混在率は平均 $9.1 \%$ であった。一方 LHRH 反応型の4 例では全例 PRL 陽性 
Table 2 Histological and endocrinological findings in 13 patients with GH-secreting pituitary adenoma and hyperprolactinemia

\begin{tabular}{|c|c|c|c|c|c|c|c|}
\hline \multirow[t]{2}{*}{$\begin{array}{l}\text { Case } \\
\text { No. }\end{array}$} & \multirow[t]{2}{*}{$\begin{array}{l}\text { Age, } \\
\text { Sex }\end{array}$} & \multirow{2}{*}{ 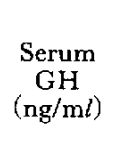 } & \multirow[t]{2}{*}{$\begin{array}{c}\text { Serum } \\
\text { PRL } \\
(\mathrm{ng} / \mathrm{m} l)\end{array}$} & \multicolumn{2}{|c|}{$\begin{array}{l}\text { Percentages of } \\
\text { immunoreactive } \\
\text { cells }\end{array}$} & \multirow{2}{*}{$\begin{array}{l}\text { Type } \\
\text { of } \\
\text { tumor }\end{array}$} & \multirow[t]{2}{*}{ Response* } \\
\hline & & & & GH & PRL & & \\
\hline 1 & $53, \mathrm{M}$ & 28.9 & 37.1 & 3.6 & 17,3 & A & TRH \\
\hline 2 & $41, M$ & 63.0 & 31.0 & 12.4 & 24.9 & $\mathrm{~A}$ & TRH \\
\hline 3 & $10, F$ & 57.5 & $1,000.0$ & 10.4 & 29.7 & $\mathbf{M}$ & TRH \\
\hline 4 & $60, \mathbf{M}$ & 36.2 & 36.2 & 15.8 & 9.8 & $\mathbf{M}$ & TRH \\
\hline 5 & $11, \mathrm{M}$ & 44.5 & 36.2 & 5.2 & 14.0 & $\mathrm{G}$ & TRH \\
\hline 6 & $31, F$ & 18.0 & 25.0 & 2.2 & 19.2 & $\mathrm{~A}$ & TRH \\
\hline 7 & $33, \mathrm{M}$ & 83.7 & 39.6 & 14.0 & 13.6 & $\mathbf{M}$ & TRH \\
\hline 8 & $46, M$ & 198.3 & 45.2 & 25.1 & 15.0 & A & TRH \\
\hline 9 & $47, M$ & 28.0 & 85.0 & 58.3 & 8.2 & A & TRH \\
\hline 10 & $50, \mathrm{M}$ & 37.0 & 29.0 & 9.9 & 24.8 & A & TRH \\
\hline 11 & $42, F$ & 20.8 & 37.2 & 11.6 & 0.8 & $\mathrm{M}$ & NON \\
\hline 12 & $30, F$ & 174.0 & 67.3 & 0.9 & 0.0 & $\mathrm{~A}$ & NON \\
\hline 13 & $45, F$ & 53.0 & 39.0 & 9.5 & 0.5 & $\mathbf{M}$ & NON \\
\hline
\end{tabular}

*TRH: A significant increase in serum GH occurred after thyrotropin releasing hormone (TRH) injection. NON: No significant increase occurred after TRH or luteinizing hormone releasing hormone (LHRH) injection. A indicates acidophilic; M, mixed; C, chromophobe.

細胞が存在したが，その平均混在率は1.25\%であり，無反 応型を示した11例では PRL 陽性細胞は 7 例 $(63.6 \%)$ に存 在し，平均混在率は $1.31 \%$ でった。すなわち，TRH 反 応型症例山 LHRH 反応型症例に比べて PRL 陽性紏胞の 混在率が高く，また無反応型症例と比べるとその陽性率拉 よび混在率ともに著しく高かった．高PRL 血症を合併し た13例中には TRH 反応型が10例含まれていたが，PRL 細胞の淈在率は全例 $8 \%$ 以上を示し，平均混在率は $17.6 \%$ と非常に高加た。これに対し残りの 3 例は無反応型の高 PRL 血症合併例であり，これら 3 例の PRL 陽性細胞の混 在率は全例 $1 \%$ 以下，平均 $0.4 \%$ とわわて低かった。守 なわち，無反応型例に㧍汁る高 PRL 血症の原因が腫瘍内 のPRL 細胞である可能性任低いと推測された。この傾向 は正常 PRL 值27例に抢いても汪住同椂であり，TRH反 応型15例に括いては PRL 細胞の平均混在率は $3.4 \% て ゙ ，$ $2 \%$ 以上の混在率を認めたのが 8 例 (53.3\%)であったのに 対し，LHRH 反応型や無反応型を示した12例に拈ける PRL 細胞の平均混在率は $1.1 \%$ で，混在率 $2 \%$ 以上は 1 例 (8.3\%)のみであった。

\section{3）電䫓所見の結果}

GH 産生下垂体腺腫は，電䫓的にはdensely granulated GH cell と sparsely granulated GH cell に大きく分類され
Table 3 Histological and endocrinological findings in 27 patients with GH-secreting pituitary adenoma and normal serum PRL levels

\begin{tabular}{|c|c|c|c|c|c|c|c|}
\hline \multirow[t]{2}{*}{$\begin{array}{l}\text { Case } \\
\text { No. }\end{array}$} & \multirow[t]{2}{*}{$\begin{array}{l}\text { Age, } \\
\text { Sex }\end{array}$} & \multirow{2}{*}{$\underset{\substack{\mathrm{GH} \\
(\mathrm{ng} / \mathrm{m} l)}}{\text { Serum }}$} & \multirow{2}{*}{$\begin{array}{l}\text { Serum } \\
\text { PRL } \\
(\mathrm{ng} / \mathrm{m} l)\end{array}$} & \multicolumn{2}{|c|}{$\begin{array}{l}\text { Percentages of } \\
\text { immunoreactive } \\
\text { cells }\end{array}$} & \multirow{2}{*}{$\begin{array}{l}\text { Type } \\
\text { of } \\
\text { tumor }\end{array}$} & \multirow[t]{2}{*}{ Response ${ }^{*}$} \\
\hline & & & & GH & PRL & & \\
\hline 1 & $59, \mathrm{~F}$ & 30.0 & $\leqq 20$ & 20.7 & 11.6 & $\mathbf{M}$ & TRH \\
\hline 2 & $51, F$ & 9.3 & 13.2 & 60.8 & 17.3 & $\mathbf{M}$ & TRH \\
\hline 3 & $52, \mathrm{M}$ & 11.7 & 9.3 & 5.7 & 2.8 & A & TRH \\
\hline 4 & $33, \mathrm{M}$ & 52.3 & $\leqq 20$ & 13.6 & 4.1 & $\mathbf{M}$ & TRH \\
\hline 5 & $49, \mathrm{M}$ & 90.5 & 3.9 & 3.7 & 0.6 & A & TRH \\
\hline 6 & $55, \mathrm{M}$ & 375.0 & 3.2 & 3.8 & 0.8 & $\mathbf{M}$ & TRH \\
\hline 7 & $39, \mathrm{M}$ & 96.0 & 10.0 & 1.0 & 0.6 & A & TRH \\
\hline 8 & $33, \mathrm{M}$ & 40.8 & 5.3 & 12.0 & 1.0 & $\mathbf{M}$ & TRH \\
\hline 9 & $45, M$ & 58.0 & 10.2 & 1.2 & 0.3 & C & TRH \\
\hline 10 & $33, \mathrm{M}$ & 19.8 & 5.1 & 5.5 & 3.6 & $\mathbf{M}$ & TRH \\
\hline 11 & $22, \mathbf{F}$ & 7.9 & 9.2 & 45.9 & 0.4 & A & TRH \\
\hline 12 & $38, \mathrm{M}$ & 56.3 & 14.0 & 0.0 & 2.5 & A & TRH \\
\hline 13 & $37, F$ & 43.9 & 11.3 & 5.5 & 2.7 & $\mathbf{M}$ & TRH \\
\hline 14 & $48, F$ & 40.0 & 2.0 & 2.8 & 0.4 & $\mathbf{M}$ & TRH \\
\hline 15 & $29, F$ & 92.0 & 12.0 & 24.6 & 2.2 & $\mathbf{M}$ & TRH \\
\hline 16 & $32, \mathrm{M}$ & 163.9 & 1.2 & 0.0 & 1.3 & $\mathbf{M}$ & LHRH \\
\hline 17 & $33, F$ & 46.3 & 3.4 & 7.5 & 1.8 & $\mathbf{M}$ & LHRH \\
\hline 18 & $25, \mathrm{~F}$ & 13.0 & 3.4 & 7.7 & 1.2 & $\mathbf{M}$ & LHRH \\
\hline 19 & $43, F$ & 40.0 & 6.5 & 2.7 & 0.7 & A & LHRH \\
\hline 20 & $38, \mathrm{M}$ & 385.0 & 2.1 & 0.8 & 0.0 & A & NON \\
\hline 21 & $29, \mathbf{F}$ & 7.8 & 4.4 & 6.9 & 5.4 & C & NON \\
\hline 22 & $35, \mathrm{M}$ & 28.5 & 2.9 & 0.0 & 0.0 & A & NON \\
\hline 23 & $36, \mathrm{M}$ & 72.0 & 12.6 & 9.7 & 0.9 & A & NON \\
\hline 24 & $33, F$ & 45.5 & 20.2 & 5.7 & 0.0 & A & NON \\
\hline 25 & $42, F$ & 68.0 & 21.0 & 15.2 & 0.7 & A & NON \\
\hline 26 & $35, \mathrm{M}$ & 32.9 & 12.3 & 0.5 & 0.2 & A & NON \\
\hline 27 & $12, F$ & 17.0 & 18.0 & 3.4 & 0.7 & $\mathbf{M}$ & NON \\
\hline
\end{tabular}

*TRH and LHRH: A significant increase in serum GH occurred after TRH or LHRH injection. NON: No significant increase in GH occurred after TRH or LHRH injection.

る6゙が，多くは両者が種々の割合で混在していた。よっ て, 腫瘍中に存在する $\mathrm{GH}$ 細胞が densely granulated $\mathrm{GH}$ cell dominant $の$ もを densely granulated type とし, sparsely granulated GH cell dominant $の$ 場合には sparsely granulated type とした。 GH 産生下垂体腺腫40例中, densely granulated type 上考えられたのは27例(67.5\%), sparsely granulated type は13例(32.5\%)であった。正常 PRL 值症 例27例では densely granulated type 20例(74.1\%), sparsely granulated type 7 例(25.9\%)であり，高PRL 血症を合併 する13例に関しては densely granulated type 8 例 (61.5\%)， sparsely granulated type 5 例 $(38.5 \%)$ で, 高 PRL 血症合併 
Table 4 Presence of immunoreactive PRL-secreting cells and response of serum GH to TRH or LHRH administration in patients with GH-secreting pituitary adenomas

\begin{tabular}{llcc}
\hline Response* & Serum PRL & $\begin{array}{c}\text { No. of } \\
\text { cases }\end{array}$ & $\begin{array}{c}\text { Mean percentage of } \\
\text { immunoreactive } \\
\text { PRL-secreting cells }\end{array}$ \\
\hline TRH & normal & 15 & $3.39 \pm 4.62$ \\
& high & 10 & $17.65 \pm 6.63$ \\
LHRH & normal & 4 & $1.25 \pm 0.39$ \\
& high & 0 & 0 \\
NON & normal & 8 & $0.99 \pm 1.70$ \\
& high & 3 & $0.43 \pm 0.33$ \\
\hline
\end{tabular}

*See Table 3.

例の特徵は認められなかった。ささらに、いわゆる acidophil stem cell adenoma や mammosomatotroph cell adenoma の所見6諰められなかった。

一方, 高 PRL 血症合併例の PRL 細胞飞関 L電影的に 観察した範囲内においては，6例にPRL 細胞(sparsely granulated PRL cell) が確認できた(Fig. 4)。ささら，高 PRL 血症を認めながら光顕的免疫染色て腫瘍内に PRL 陽 性細胞がみられないかあるいはきわぬてその混在率が低か った 3 例に批いては，電顕上も PRL 細胞は認められなか った。

\section{$\mathbf{N}$ 考察}

\section{1. 高 PRL 血症の原因}

周知のごとく，一般に高 PRL 血症の原因としては，(1) 腫瘍細胞自体から産生される腫瘍分泌型，(2)視床下部上り のPRL 分泌抑制因子，すなわちPIFの障害に起因寸る PIF 障害型，(3)種々の原因による下垂体加らのPRLの hypersecretionなどが考えられている．高PRL 血症を合併 する GH 産生下垂体腺腫火括いても，その高 PRL 血症の 原因々しては同样の観点からその発症機転が検討されなけ ればならない。

腫瘍分泌型：以前より，動物実験では自然誘発下垂体腺 腫 ${ }^{2)}$ や estrogen 誘発下垂体腺腫 ${ }^{8)}$ において GHおうよび PRL の両亦ルモンの分泌が示されており，放射線誘発下垂体腺 畽 ${ }^{13)}$ では GH やPRLの及ならず adrenocorticotropic hormone (ACTH) b分泌子る。ヒに括いては，Kovacs 56) が(1) GH と PRLが異なった細胞より産生されるものとし $\tau$ mixed GH cell-PRL cell adenoma, (2) GH $と$ PRL が同 一細胞より産生されるものとして acidophil stem cell adenomaあるいは mammosomatotroph cell adenoma と分類 し，これらは電顕的に鑑別しらるとした。なた，GHや

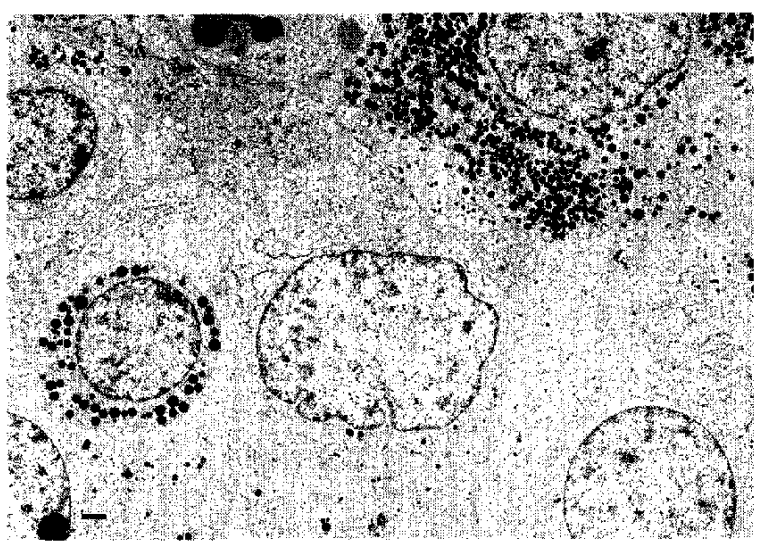

Fig. 4 Densely granulated GH cells and sparsely granulated PRL cells are present. $B a r=1 \mu \mathrm{m}$.

PRLだけでなく他のホルモン産生す合併した multihormone producing adenomaの報告11)むなれている.

高PRL 血症合併例に括忖るPRL 分泌の原因が腫楊自 体にあるか否かに関して，腫煌組織構築像，通常の光顕手 法による細胞質内の染色性とい5点に执いて，Kovacs $5^{6)}$ が mixed GH cell-PRL cell adenoma $の$ 多くは diffuse type $て$ あるが sinusoidal type 存在すること，そしてその細胞質 は acidophilic, mixed，あるいは chromophobicであると述 ベているように，自験例からもその特徵は見い出せず従来 の報告と同様であった。

一方，免度組織化学的手法の貢献度は大きく Lamberts $5^{7)}$, Kanie $\dot{b}^{4)}$, Nieuwenhuijzen Kruseman $5^{9)}$ は，GH 産生下垂体腺腫症例において PRL 陽性細胞が認 められるのは，それぞれ35例中 14 例 $(40 \%) ， 55$ 例中 25 例 (45\%)，34例中12例(35.3\%)であった上述べ，PRL 細胞 陽性例江执いて高 PRL 血症を合併寸るのが，それぞ机14 例中 10 例 $(71.4 \%) ， 25$ 例中 15 例 $(60 \%) ， 12$ 例中 6 例 $(50 \%)$ であったと報告している．腫瘍中のホルモン陽性細胞の所 見と血中ホルモン值との関係について，Zimmerman ら ${ }^{14)}$ 腫瘍中の GH 拉よび PRLに対する免疫反応の所見 と血中 GH・PRL 值はよく相関すると報告したが，Nieu一 wenhuijzen Kruseman $5^{9)}$ は PRL陽性細胞の所見と高 PRL 血症の間に有意の相関はないとした。このよ5に従 来の報告を概括すると，GH 産生下垂体腺腫症例の30 $50 \%$ 亿抋いて腺腫中に GH 細胞以外飞も PRL 細胞を認め ているが，腫瘍中の GH 拉よび PRL 陽性細胞の所見とそ れぞれの血中ホルモン值との相関の有無関しては，一定 した見解が得られていない。ところが，我及の検索した GH 産生下垂体腺腫40例飞打いて 有無にかかわらず，腺腫中の PRL陽性細胞の存在すなわ 
ち陽性率は高率(90\%)であること，扎よび(2)腺腫中の PRL 陽性細胞の混在率と血中 PRL 值との間に正の相関を 認めることの2 点が新たに明らかとなった。我々はこの2 つの所見から， $\mathrm{GH}$ 産生下垂体腺腫の大部分は元来腺腫中 に GH 細胞のみならず PRL 細胞を有するいわゆる mixed GH cell-PRL cell adenoma の形で存在するものであり，な んらかの誘因で PRL 种胞が增殖したりPRL 分泌機能が 充進する際に高PRL 血症を呈するのであるうと推論し た。

ここで当然疑問ないし問題となるのは，我々が明確にし えたこれらの所見が従来の報告では明らかにされていなか った理由についてであるが，(1)我々は組織標本を丹念に鏡 挨した上で腫葟性の増殖を示す部位に明らかなホルモン陽 性細胞を認める場合には，その混在率が低くてもホルモン 陽性細胞存在としたこと，(2)腫瘍内のホルモン陽性細胞の 混在率は腫瘍内の部位によってかなり異なる症例も認めら れるため，組織標本中数力所を選抧し，その平均混在率上 血中ホルモン濃度との関係を検討したことなどが挙げられ る.

PIF 障害型：高 PRL 血症合併例で腺腫中に PRL 陽性 細胞が存在しないかあるいはきわめてとの混在率の低い3 例に関し，1 例仙著明な鞍上部進展をきたした症例でPIF 障害が示唆された。Adelman ${ }^{1}$ や Nieuwenhuijzen Kruseman ら ${ }^{9)}$ も，高 PRL 血症合併例て腺腫中のPRL 陽性細胞 所見の乏しいるのに対してはPIF 障害型を示唆している. 残りの 2 例についても，著明な鞍上部進展が認められない からといって，高 PRL 血症の原因が PIF 障害ではないと は断言できない。しかしながら，高 PRL 血症をきたす薬 剂の使用歴などもなく，その機序を明確には指摘し吝なか った。

2. TRH および LHRH 負荷による血中 GH 值の異常反 応との関連

GH 産生下垂体腺腫に斿けるTRH および LHRHによ る血中 GH 值の反応性に拈いて, Nieuwenhuijzen Kruseman 59) は高 PRL 血症合併例 13 例中 8 例が TRH 反応型 で，そのうち 6 例の腫㾮中に PRL陽性紏胞が存在した

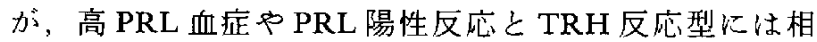
関はない上した。一方，高 PRL血症合併し腺腫中の PRL 陽性細胞を多く認める症例では TRH 反応型が多い 亡するKanie 54の報告むある。我々の症例でる高 PRL 血症を合併しかつ腺腫中の PRL 陽性細胞の混在率の高い 症例は TRH 反応型で, PRL陽性細胞の混在率の低い症 例は無反応型と二分することができた，同様の関連が

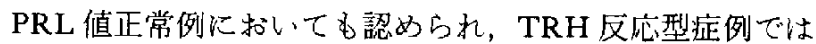
それ以外の症例に比し PRL 陽性細胞の混在率が高かっ
た。したがって，高 PRL 血症を合併している TRH 反応 型の症例は，そのPRL 分泌の原因が畽淘自体にある可能 性が高いと推測された。TRH 反応型の GH 産生下垂体腺 腫において bromocriptine が血中 GH 值を低下させる治療 効果を有するといら報告3)はきわ高味媣いが，TRH 反応型とそれ以外の反応型の $\mathrm{GH}$ 細胞の相違点について はいまだ明らかにされていないまた，TRH 反応型症例 に打计る $\mathrm{GH}$ 細胞と PRL 細胞の生物学的相関などに関し ても，今後の検討課題であ万う。

\section{$\mathrm{V}$ 結 語}

GH 産生下垂体腺腫40例飞ついて，高 PRL 血症合併例 13例と非合併例27例に分け，組織学的扣よび内分泌学的に 対比しつつ検索した.

1. 通常の光顕(HE 染色)および電影観察では，高 PRL 血症合併例と非合併例の腫瘍の間に特記すべき美異 は認められなかった。

2. 免疫染色では，高 PRL 血症の有無にかかわらず, 腺腫中に観察される PRL 陽性細胞の存在すなわち陽性率

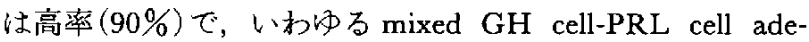
noma の形で存在した.

3. 血中 PRL 值と腺腫中の PRL 陽性細胞の密度(混在 率)に相関が認められた $(\mathbf{p}<0.05)$ 。

4. 高 PRL 血症合併例13例中に，腺畽中の PRL 陽性細 胞混在率の低い 3 例が存在した。うち 1 例では高 PRL 血 症の原因として重瘍の鞍上部進展に由来寸る PIF 障害が 推定されたが，他の 2 例では不明であった。

5. 高 PRL 血症合併例13例の5ち, 前述の PRL 陽性細 胞混在率が低い3 例はすべて無反応型で，残りの10例は TRH 反応型であった。TRH 反応型症例では腺腫中の PRL 陽性細胞の混在率が高く，この10例に括壮る高 PRL 血症の原因は腺腫中の PRL 細胞に起因する可能性が高い ことが強く示唆された。高 PRL 血症非合併例27例につい ても，TRH 反応型症例では他の症例に比して腺腫中の PRL 陽性細胞の混在率が高い傾向が認められた。

\section{文献}

1) Adelman LS: The pathology of pituitary adenomas, in Post KD, Jackson IMD, Reichlin S (eds): The Pituitary Adenoma, chapter 3. New York, Plenum, 1980, pp 47-61

2) Berkvens JM, Nesselrooy JHJ, Kroes R: Spontaneous tumors in the pituitary gland of old Wistar rats. A morphological and immunocytochemical study. J Pathol 130: 179-191, 1980

3) Ishibashi M, Yamaji $T$, Kosaka K: Effect of bromoergocriptine on TRH-induced growth hormone and prolactin release in acromegalic patients. $J$ Clin Endocrinol Metab 45: 275-279, 1977 
4) Kanie N, Kageyama N, Kuwayama A, Nakane T, Watanabe M, Kawaoi A: Pituitary adenomas in acromegalic patients: An immunohistochemical and endocrinological study with special reference to prolactin secreting adenoma. $J$ Clin Endocrinol Metab 57: 1093-1101, 1983

5) Kernohan JW, Sayre GP: Tumors of the pituitary gland and infundibulum, in: Atlas of Tumor Pathology, section $X_{J}$ fascicle 36 . Washington, DC, Armed Forces Institute of Pathology, 1956, pp 1-81

6) Kovacs $\mathrm{K}$, Horvath $\mathbf{E}$ : Tumors of the pituitary gland, in Hartmann WH (ed): Atlas of Tumor Pathology, second series, fascicle 21. Washington, DC, Armed Forces Institute of Pathology, 1986, pp 70-133

7) Lamberts SWJ, Klijn JGM, Vroonven GCJ, Stefanko SZ, Liuzzi A: The role of prolactin in the inhibitory action of bromocriptine on growth hormone secretion in acromegaly. Acta Endocrinol (Copenh) 103: 446-450, 1983

8) McComb DJ, Ryan N, Horvath E, Kovacs K, Nagy E, Berczi I, Domokos I, Laszio FA: Five different adenomas derived from the rat adenohypophysis: Immunocytochemical and ultrastructural study. JNCI 66: 1103-1111, 1981

9) Nieuwenhuijzen Kruseman AC, Bots GTAM, Frolich M, Van Dulken $\mathrm{H}$ : Immunocytochemical growth hormone and prolactin in pituitary adenomas causing acromegaly and their relationship to basal serum hormone levels and growth response to thyrotrophin releasing hormone. Clin Endocrinol (Oxf) 19: 1-8, 1983

10) Russell DS, Rubinstein LJ: Pathology of Tumours of the Nervous System, ed 4. London, Edward Arnold, 1977, pp 312-330

11) Scanarini $M$, Mingrino $S$ : Pituitary adenomas secreting more than two hormones. Acta Neuropathol (Berl) 48: 67-72, 1979

12）寺本 明：ホルモン産生下垂体腺腫の免疫組織化学的検討. 脳と神 32: 1163-1173, 1980

13) Yokoro $K$, Furth J, Haran-Ghera N: Induction of mammotropic tumors by $\mathrm{X}$-rays in rats and mice: The role of mammotropes in development of mammary tumors. Cancer Res 21: 178191,1961

14) Zimmerman E, Defendini R, Frantz AG: Prolactin and growth hormone in patients with pituitary adenomas: A correlative study of hormone in tumor and plasma by immunoperoxidase technique and radioimmunoassay. $J$ Clin Endocrinol Metab 38: 577-585, 1974

〔別刷請求先 : $=734$ 広島市南区霞 $1-2-3$ ，広島大学脳神経外科， 河島研吾了 